Aurel Nuro ${ }^{*}$, Elda Marku ${ }^{1}$, Bledar Murtaj ${ }^{1}$, Valbona Plaku

${ }^{1}$ Tirana University, Faculty of Natural Sciences, Chemistry Department, Tirana, Albania, ${ }^{2}$ Tirana Polytechnic University, General and Inorganic Chemistry Department, Tirana, Albania
Scientific paper

ISSN 0351-9465, E-ISSN 2466-2585

UDC:628.191/.196(497.5)

doi: $10.5937 /$ ZasMat $1702212 \mathrm{~N}$

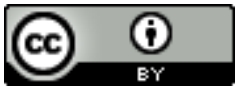

Zastita Materijala 58 (2)

$212-221(2017)$

\title{
Determination of some organic pollutants in waters rivers of Tirana city
}

\begin{abstract}
This study presented data about concentrations of some organic pollutants in two main rivers of Tirana city: Lana River that crosses through the city and Tirana River that lies in northeast of the city. Twenty stations were analyzed in this study. Sampling of water was realized in July 2016. These rivers present important aquatic areas of Tirana region in Albania. For both water river samples were analyzed organochlorine pesticides (OCPs), their degradation products, polychlorinated biphenyls (PCBs), BTEX (benzene, toluene, ethylbenzene and o-, $m-, p$-xylenes) and polyromantic hydrocarbons (PAH). For extraction of OCPs and PCBs by water samples were used liquid-liquid (LLE) extraction and n-Hexane as extracting solvent. After clean-up and concentration procedures for all samples were performed gas chromatographic analyzes using Rtx-5 capillary column ( $30 \mathrm{~m} \times 0.33 \mathrm{~mm} \times 0.25 \mathrm{um}$ ) and electron capture detector (GC/ECD). Headspace solid phase micro extraction (HS-SPME) technique was used to trace BTEX in water samples. For isolation of PAH, LLE extraction assisted with Dichloromethane as extraction solvent were used. The extracts were concentrated and then were injected in gas chromatograph. The analysis of BTEX and PAH in water samples was performed by gas chromatography technique using flame ionization detector (GC/FID). Injections of BTEX were done directly by using HeadSpace mode of Polydimethyl Siloxane fiber. VF-1ms capillary column ( $30 \mathrm{~m} \times 0.33 \mathrm{~mm} \times 0.25 \mathrm{um}$ ) was used for separation of BTEX and PAH compounds.

The higher concentrations of organochlorine pesticides and PCBs were found for water samples of Tirana River because of their previous use, in the agricultural areas near the basin of this river. The higher concentrations were for volatile PCBs because of their atmospheric deposition in Albanian territory. Relatively high concentrations of BTEX and more volatile PAH compounds were detected in water samples of Lana River. The presence of volatile organic pollutants could be mostly of automobilist transport near the stations, discharging of wastes from some gas stations or some mechanical industries neat the river.
\end{abstract}

Keywords: Tirana River; Lana River; OCP; PCB; BTEX; PAH; LLE; HS-SPME; GC/ECD; GC/FID.

\section{INTRODUCTION}

Tirana city is capital of Albania. After 90' Tirana city is growing fast. It is located in Central Albania, at the western foot of the Dajti Mountain at an altitude of $110 \mathrm{~m}$. The Adriatic Sea is only 30 kilometers away in a linear distance. In south and west of Tirana lie some hills that form a green belt around the city. At the north of Tirana runs the river with the same name, one of the headwaters of the river Ishem. A few kilometers south of Tirana flows

\footnotetext{
${ }^{*}$ Corresponding author: Aurel Nuro

E-mail: aurel.nuro@fshn.edu.al

Paper received: 12. 03. 2017.

Paper accepted: 25. 04. 2017.

Paper is available on the website: www.idk.org.rs/journal
}

the river Erzen and the city center is crossed by Lana stream that springs in Dajti Mountain. The Tirana River is a source of the Gjole River. Its basin area is in the mountains northeast of Tirana, near the village Zall-Dajti. It flows along the northern of Tirana city, and joins to the Terkuza near the Preza Village to form the Gjole River. The Lana is the main stream that crosses through Tirana. Its basin area is in the mountains east of Tirana. Although once clean, it now carries sewages of many buildings and small businesses near the river. During the 1990s, many illegal buildings were constructed near the river. No fish live there now due to the high pollution of its waters. The Lana River flows into the Tirana River near Berxulli village [1]. Both Tirana and Lana rivers are two important ecosystems of Tirana city for this they need proper attention. 
Organic pollutants, in particularly hydrocarbons and chlorinated pollutants, such as; BTEX, PAH, organochlorine pesticides, PCBs, Dioxins, etc, have been known to persist for long time in soils, water, sediments and biota of many ecosystems. Before years 90' organochlorine pesticides were widely used in Albania for agricultural purposes. The western part of the country are the main agricultural areas, but different directions of agricultural (fruits, corns, vegetables, etc.), everywhere in the country had been developed. Organochlorine pesticides as: DDT, Lindane, HCB, Aldrins and Heptachlors were widely used. After years 90' the scale of pesticides used in agriculture has decreased, due to the change of land use. The expired pesticides by the former, has generated. These pesticides have been damaged due to the inappropriate conditions of conservation and storage. The other part of expired or out of use pesticides, to be disposed of conservation, in various districts of the country, has been distributed. Commercial PCB mixtures were used after 90' in Albania, mainly, either as dielectric fluids in capacitors and transformers or as heat exchange fluids. The same properties which make PCBs interesting for industrial use cause adverse effects on reproduction, development, and endocrine function [2,3]. Volatile PCB levels were reported in many studies realized in different Albanian ecosystems. Probably, atmospheric deposition is considered to be the main factor of PCB pollution in Albania. Benzene, Toluene, Ethylbenzene and Xylenes (BTEX) are also major constituents of gasoline. Exhaust emissions from vehicles, as well as evaporative losses from gasoline stations and vehicles, are major sources of BTEX that are released in the atmosphere. Because of their ability to persist in the atmosphere from days to weeks, and because they will, in part, dissolve into water, BTEX are expected to be present in air, waters, soil and sediments. In the atmosphere BTEX provide a non-point, low concentration source to the hydrologic cycle as a result of the dispersive effect of weather patterns and the occurrence of precipitation. The volatilization of BTEX occurs slowly from ponds and lakes, as well as from slow-moving and deep streams and rivers. Benzene and other monocyclic hydrocarbons were found to be problematic for the environment and the humans [4]. These compounds are released into the environment during manufacture, transportation, usage, and disposal, leakage in underground storage tanks and pipelines in gasoline industry, and through leachate from landfills. Polyaromatic hydrocarbons are a large group of compounds with a molecular structure that includes two or more fused aromatic rings. They are widely distributed in the environment as a result of the incomplete combustion of organic materials, both of natural (e.g. forest fires) and anthropogenic sources (e.g. motor vehicles, industrial processes,). The spillage of fossil fuel can be a significant source of contamination, as well as the leaching from pipes $[5,6]$.

Liquid-Liquid Extraction (LLE) and Solid Phase Extraction (SPE) is the technique most frequently used for analysis of POPs (include OCPs, PCBs and PAHs) in surface and waste water samples. For low levels of pollutants large volume of samples needed. Liquid-liquid extraction is a routine analysis used in many laboratories. Purge and trap (P\&T) is the most frequently applied technique for the extraction and concentration of BTEX and other volatiles in water [7]. However, this method can produce false quantification due to contamination in the P\&T system with target and non-target compounds with similar retention times in the presence of high concentrations of hydrocarbons. Headspace solid phase micro-extraction (HS-SPME) is highly sensitive method for BTEX analysis in water samples [8]. This method is characterized by rapid and automatic extraction.

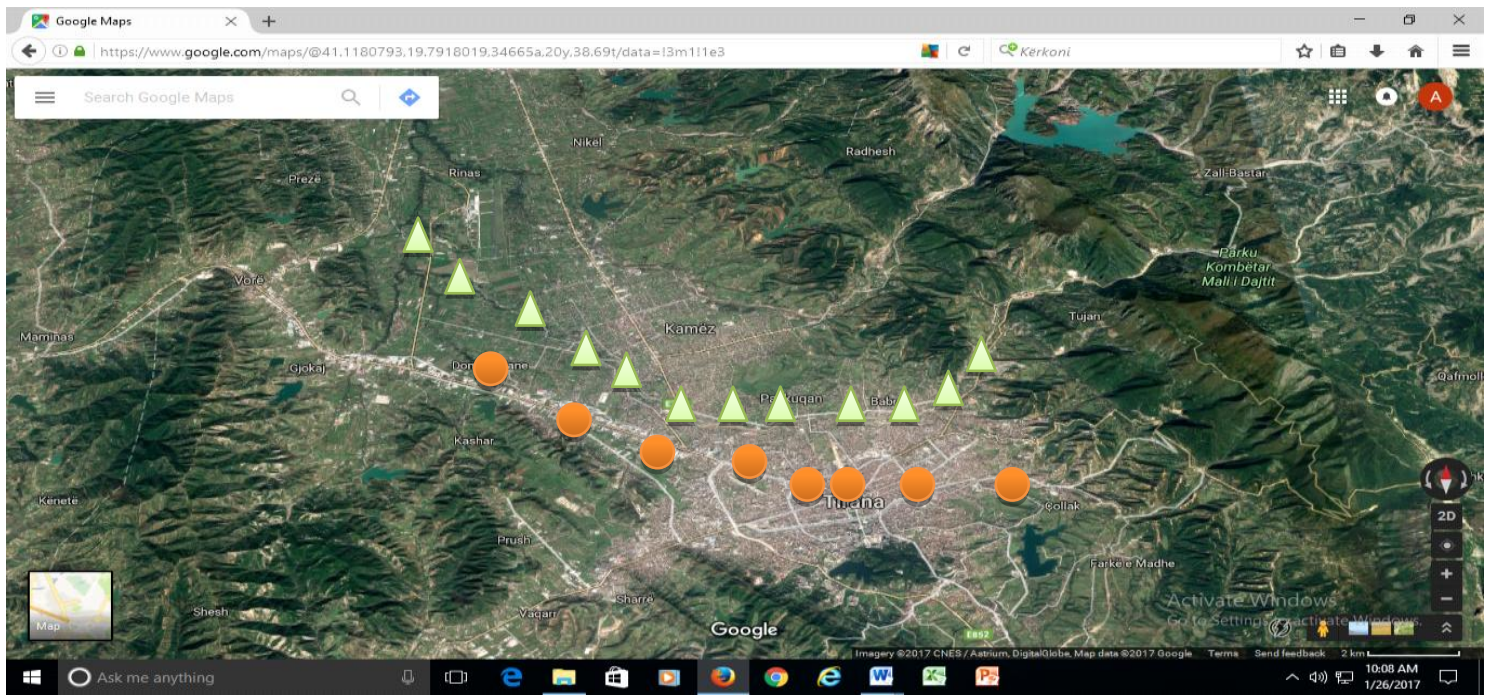

Figure 1. The map of sampling of water samples in Tirana River ( $\triangle$ ) and Lana River ( $)$ Slika 1. Mapa uzorkovanja vode u reci Tirani $(\triangle)$ i reci Lani $(\bigcirc)$ 


\section{EXPERIMENTAL}

\subsection{Sampling of water samples in Tirana and Lana rivers}

Twenty stations were analyzed in this study. Sampling of water was realized in July 2016. Twelve water samples were taken in different stations of Tirana River. The samplings in Lana River were realized for 8 stations. The sampling sites for water samples in Tirana River and Lana River are presented in Figure 1. 1.5L of water were taken from each station. Water samples were tranported in $+4^{\circ} \mathrm{C}$.

\subsection{Preparation of water samples for OCP and $P C B$ analyzes}

Chlorinated pesticides and PCBs in water samples were extracted using liquid-liquid extraction (LLE) assisted with Hexane solvent. 1L of water and $20 \mathrm{ml}$ Hexane as extract solvent was added in a separatory funel. After shaking organic phase was collected in a beker when was added $5 \mathrm{~g} \mathrm{Na}_{2} \mathrm{SO}_{4}$ anhidrous for removing water. After concentration in $1 \mathrm{ml}$ Hexane, the samples were injected directly to GC/ECD for simultaneous of chlorinated pesticides and PCBs $[9,10]$.

\subsection{Preparation of samples for BTEX analyzes}

Headspace solid phase micro extraction (HSSPME) technique was used to trace BTEX in sediment and water samples. $5.0 \mathrm{gr}$ sediment and $5.0 \mathrm{~mL}$ of water sample was placed in a $10 \mathrm{~mL}$ headspace vial (5 replicate vials for each sample) to adsorb BTEX. The vials were placed in a heating block for $45 \mathrm{~min}$ at $50^{\circ} \mathrm{C}$. Extraction of volatile compounds was done using a $100 \mu \mathrm{m}$ Polydimethylsiloxane fibre in a SPME manual holder [8,11]. Direct injection in HS mode was performed in $280^{\circ} \mathrm{C}$ in a PTV injector.

\subsection{Preparation of water samples for $P A H$ analyzes}

$\mathrm{PAH}$ in water samples were extracted using liquid-liquid extraction (LLE) assisted with Dichloromethane solvent. $1 \mathrm{~L}$ of water and $20 \mathrm{ml}$ Dichloromethane as extract solvent was added in a separatory funel. After shaking organic phase was collected in a beker when was added $5 \mathrm{~g} \mathrm{Na}_{2} \mathrm{SO}_{4}$ anhidrous for removing water. After concentration in $1 \mathrm{ml}$ Dichloromethane, the samples were injected directly to GC/FID [5].

\subsection{Apparatus and chromatography}

Gas chromatographic analyses were realized with a Varian 450 GC instrument equipped with two PTV injectors and a flame ionization detector and with a ${ }^{63} \mathrm{Ni}$ electron-capture detector. The column used for isolation od chlorinated pesticides and PCBs (simultaneously) was Rtx-5 (30mx x $0.33 \mathrm{~mm}$ x 0.25 um) capillary column. The injector and detector temperatures were set at $280^{\circ} \mathrm{C}$ and $320^{\circ} \mathrm{C}$, respectively. Carrier gas was $\mathrm{He}$ at 1 $\mathrm{ml} / \mathrm{min}$ and make-up gas was nitrogen $25 \mathrm{ml} / \mathrm{min}$. The initial oven temperature was kept at $60^{\circ} \mathrm{C}$ for $4 \mathrm{~min}$, which was increased, to $200^{\circ} \mathrm{C}$ at $20^{\circ} \mathrm{C} / \mathrm{min}$, held for $7 \mathrm{~min}$, and then increased to $280^{\circ} \mathrm{C}$ at $4^{0} \mathrm{C} / \mathrm{min}$ for $20 \mathrm{~min}$. The temperature was finally increased to $300^{\circ} \mathrm{C}$, at $10^{\circ} \mathrm{C} / \mathrm{min}$, held for $7 \mathrm{~min}$. Injection volume was $2 \mu \mathrm{l}$, when splitless injections were made $[9,12]$.

VF-1ms capillary column $(30 \mathrm{~m} \times 0.33 \mathrm{~mm} \times$ $0.25 \mu \mathrm{m}$ ) was used to isolate and determine BTEX and PAH compounds in separately injections. A temperature for FID was held at $280^{\circ} \mathrm{C}$. Nitrogen was used as carrier and make-up gas for both analyses. Hydrogen and air were flame detector gases with $30 \mathrm{ml} / \mathrm{min}$ and $300 \mathrm{ml} / \mathrm{min}$, respectively. Injections of BTEX were done in injector PTV directly by using Head-Space mode $\left(280^{\circ} \mathrm{C}\right.$ for 15 seconds) of Polydimethyl Siloxane fiber $[7,8] .1 \mu \mathrm{l}$ extract in Dichloromethane (extracting solvent) were injected for PAH analyses. Quantification of BTEX and PAH was based on external standards $[6,11]$.

\section{RESULTS AND DISCUSSION}

Analysis of organic pollutants in water samples and the Tirana River and Lana River was realized in July 2016. Chlorinated organic pollutants (chlorinated pesticides, their residues and PCB) were studied using capillary GC/ECD. BTEX and $\mathrm{PAH}$ qualitative and quantitative analyze was conducted with capillary column with GC/FID technique. OCPs, PCBs and PAH were extracted using liquid-liquid extraction. Extraction and injection of BTEX were performed using Head Space mode.

Figure 1 shows the total of organochlorine pesticides in water samples of Tirana River analyzed in July 2016. The organochlorine pesticides detected were $\mathrm{HCB}, \mathrm{HCHs}$ (alpha-, beta-, gama- and delta-isomers) and the DDTrelated chemicals ( $p, p-D D E, p, p-D D D, p, p-D D T)$, Aldrines (Aldrine, Dieldrine, Endrine) and Heptachlors. The highest level was for TR9 station with $131.08 \mu \mathrm{g} / \mathrm{L}$. The low level was for TR10 sample with $10.2 \mu \mathrm{g} / \mathrm{L}$. The average level of organochlorine pesticides for all stations was 60.66 $\mu \mathrm{g} / \mathrm{L}$. The most polluted water of Tirana River was in the first part of it because in these areas are in use for agricultural purposes. The last part of the river is almost 3 to 7 time more cleaned because of dilution factor. The total organochlorine pesticide levels in Lana River water samples are shown in Figure 2. Levels of organochlorine pesticides in Lana River stations were from 31.03 to $81.2 \mu \mathrm{g} / \mathrm{L}$. The found levels were almost the same for all 
studied stations. The average levels were almost the same with the average level found in Tirana River with $64.46 \mu \mathrm{g} / \mathrm{L}$. The highest levels were for LR 7 and LR8 stations, near Berxulli village. In this last part of Lana River are large agricultural areas. This could be the main factor for the higher levels found compare with other stations. Figure 3 shows the profile of organochlorine pesticides in water samples of the Tirana River and Lana River, July 2016. $\mathrm{HCH}$, Heptachlors and Aldrines were found more than other pesticides in Tirana River. This fact is associated with previous uses of these $\mu g / l$ compounds for agricultural purposes but also with the chemistry of each individual studied pollutant (mainly with the stability and solubility of pesticides and their residues in water samples). DDT was detected in few stations not only for its previous use but can be mostly because maybe of a point source of it near the river or river effluents. Profile of organochlorine pesticides in Lana River was: Heptachlors > Aldrines > HCHs > DDTs. This profile of pesticides is associated with their previous uses in agricultural areas near the upperstream and down-stream of Lana River.

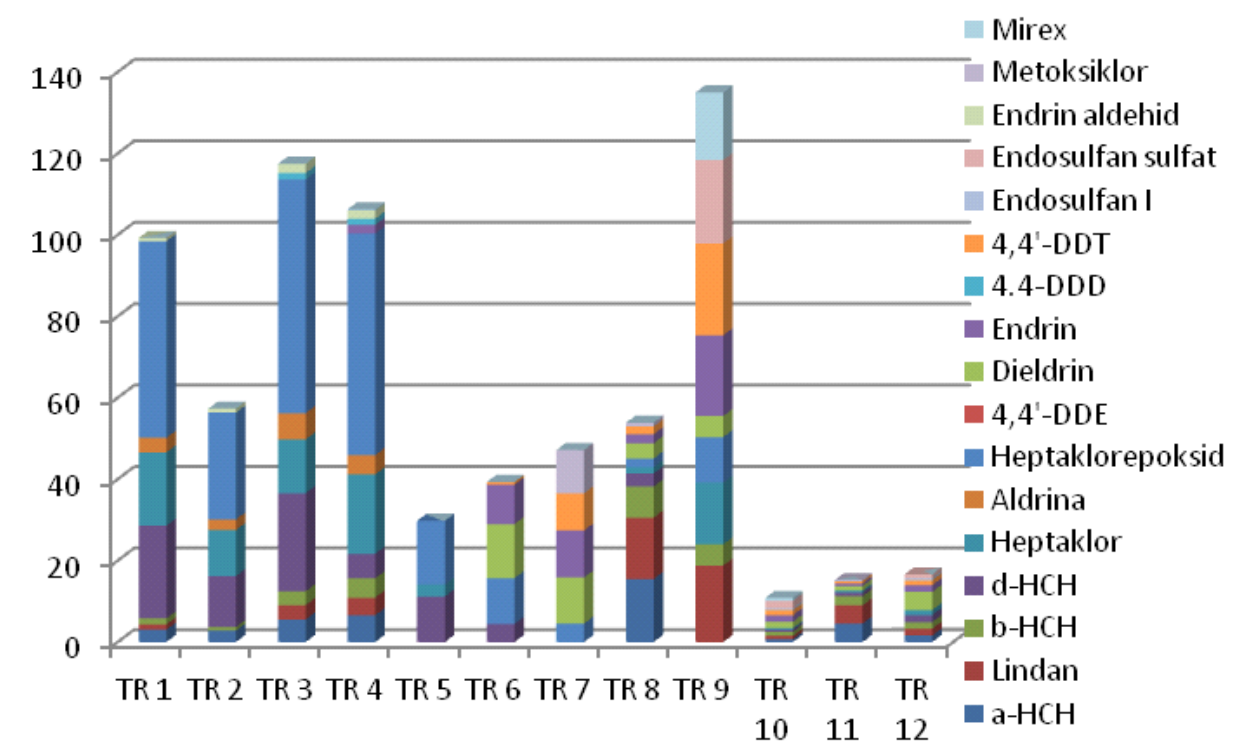

Figura 1. Total of organochlorine pesticides in water samples of Tirana River, July 2016.

Slika 1. Ukupna vrednost organohloriranih pesticida u uzorcima vode reke Tirana, juli 2016. $\mu g / l$

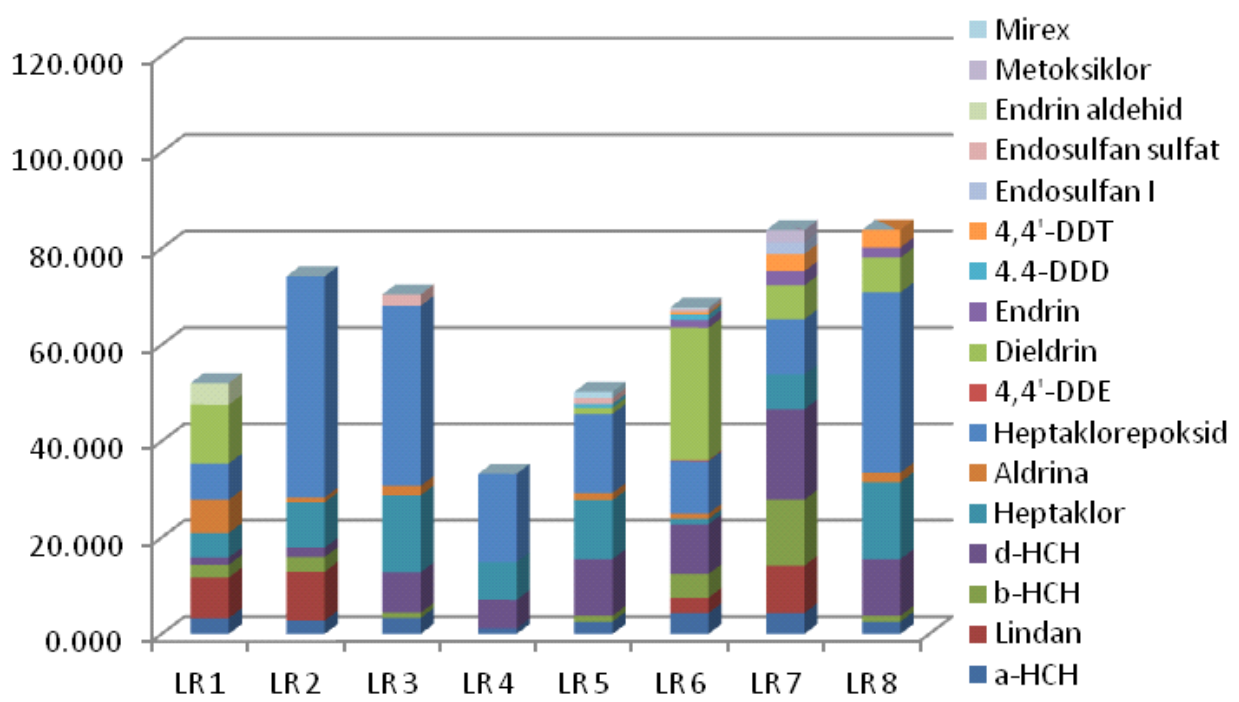

Figura 2. Total of organochlorine pesticides in water samples of Lana River, July 2016.

Slika 2. Ukupna vrednost organohloriranih pesticida u uzorcima vode reke Lana, juli 2016. 
$\mu g / l$

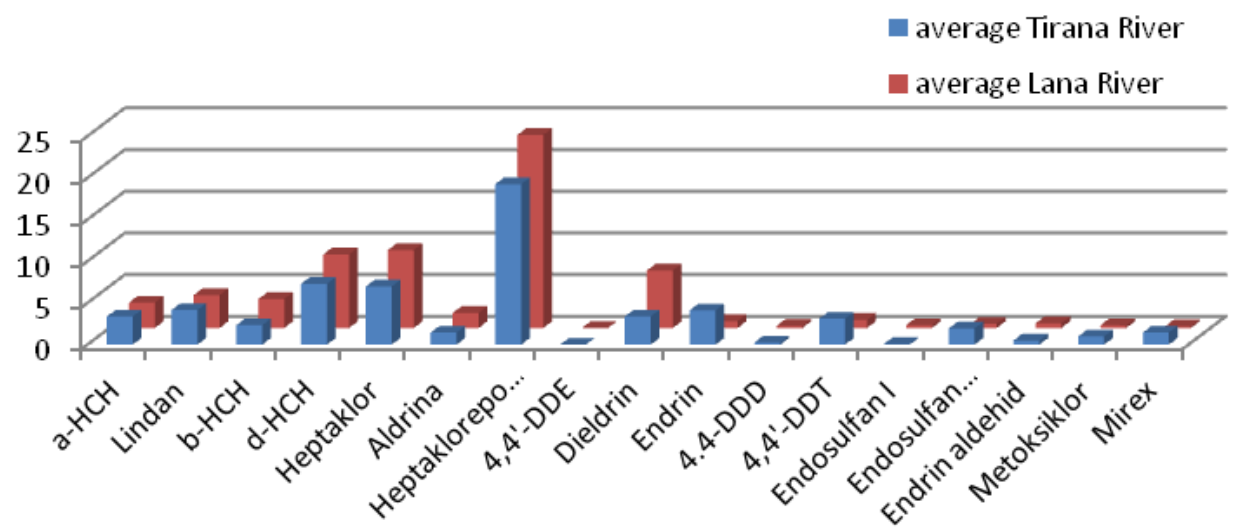

Figura 3. Profile of organochlorine pesticides in water samples of the Tirana and Lana rivers, July 2016.

Slika 3. Profil organohliriranih pesticida u uzorcima vode reka Tirana i Lana, juli 2016.

Figure 4 shows the total of PCBs in water samples of Tirana River analyzed in July 2016. Analyzes of PCBs was based on the determination of the seven PCB markers (IUPAC Nr. 28, 52, 101, 118, 138, 153 and 180). The highest levels were found for TR1 and TR9 stations respectively with 37.5 and $38.1 \mathrm{ug} / \mathrm{L}$. The low level was for TR10 sample with $5.94 \mathrm{ug} / \mathrm{L}$. The average level of PCBs for all stations of Tirana River was $20.4 \mathrm{ug} / \mathrm{L}$. The most polluted water of Tirana River with PCBs was in central stations because of some mechanical services near the river. Discharging of waste waters directly in the river cold increased the levels of PCBs and other hydrocarbons in the river. The total of seven PCB markers in Lana River water samples are shown in Figure 5. Levels of PCBs in Lana River stations were from 3.9 to $18.8 \mathrm{ug} / \mathrm{L}$. The found levels were in the same level for all studied stations. The average level in Lana River was 10.4 $\mu g / l$ $\mathrm{ug} / \mathrm{L}$. It was the half compared with the average level found in Tirana River. The highest levels were for LR3 station. Figure 6 shows the profile of PCBs in water samples of the Tirana River and Lana River, July 2016. PCB 28 was found more than other PCB markers in both Tirana River and Lana River. PCB 28 is a volatile congener. The origin of PCBs in these ecosystems is mainly because of atmospheric deposition in rivers basin. PCB 101 and 118 were also found in higher levels of almost all samples. This is mainly associated with the uncontrolled discharges of the waste water in both rivers by many mechanical businesses. Profile of PCB markers in both rivers was: PCB $28>$ PCB $101>118$ PCB > PCB $52>$ PCB 180. The main factors of PCBs pollution are atmospheric deposition in the basin areas of rivers and terrestrial sources also coming from mechanical industries.

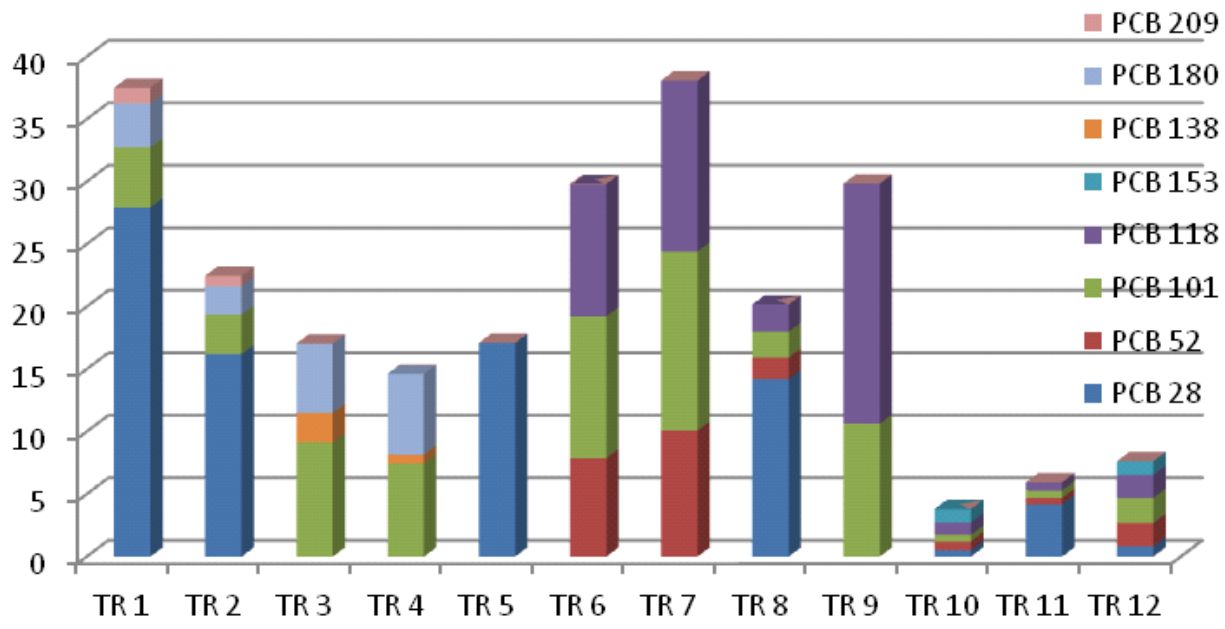

Figura 4. Total of PCBs in water samples of Tirana River, July 2016.

Slika 4. Ukupna vrednost PCBs u uzorcima vode u reci Tirana, juli 2016. 
$\mu g / l$

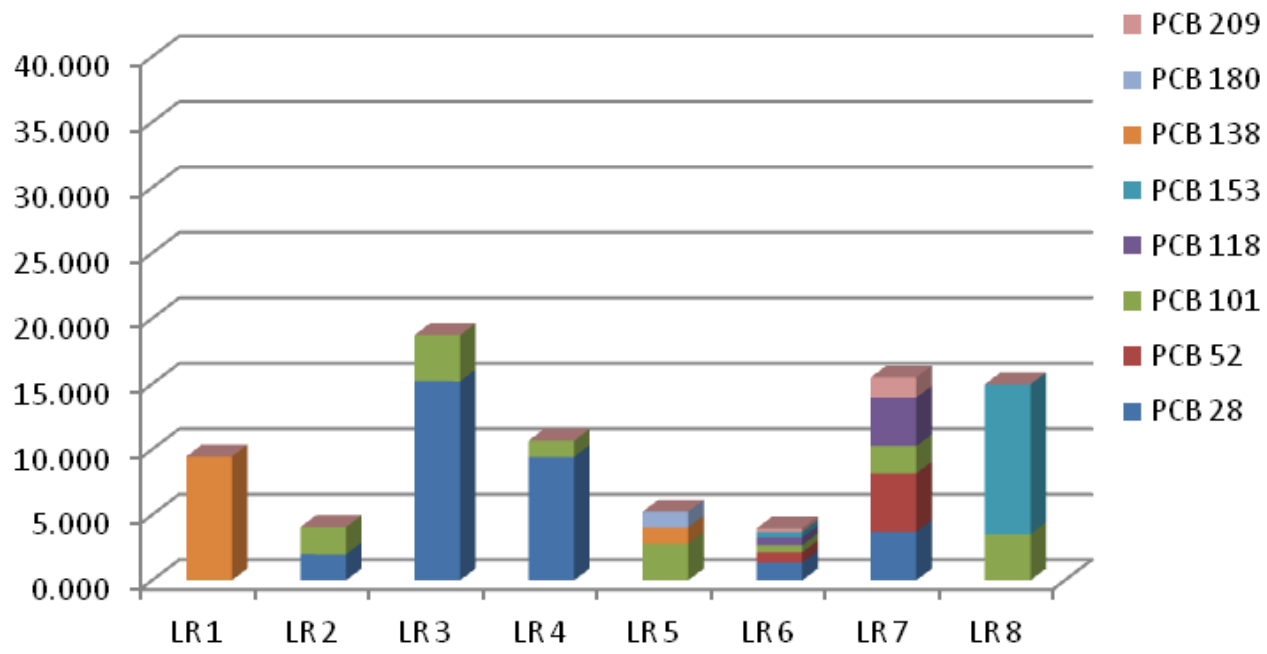

Figura 5. Total of PCBs in water samples of Lana River, July 2016.

Slika 5. Ukupna vrednost PCBs u uzorcima vode reke Lana, juli 2016.

$\mu g / l$

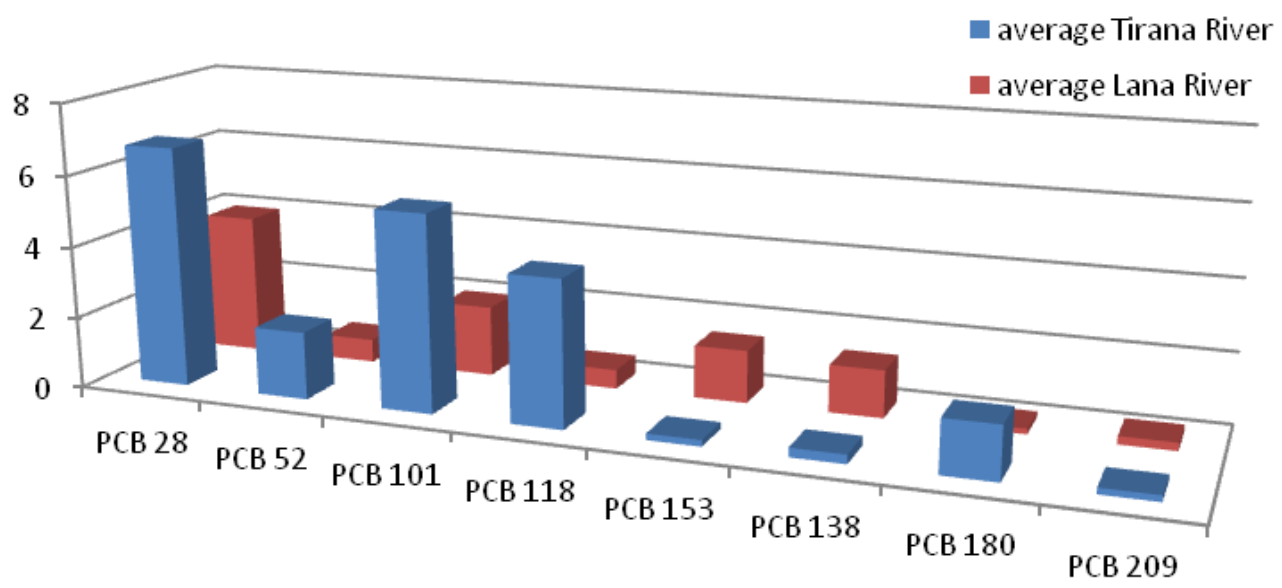

Figura 6. Profile of PCBs in water samples of Tirana River and Lana River, July 2016.

Slika 6. Profil PCBs u uzorcima vode reka Tirana i Lana, juli 2016.

Benzene, Toluene, o-Xylene, m-Xylene, $\mathrm{p}$ Xylene and Ethylbenzene (BTEX) were studied with HS-SPME followed by GC/FID in water samples. Total of BTEX in water samples for each of studied stations of Tirana River was given in Figure 7. Station TR2 was observed to have the maximum level with $14.1 \mathrm{mg} / \mathrm{L}$ and the minimum was for the station TR3 and TR5 where BTEX weren't detected. Average level of BTEX in Tirana River was $4.7 \mathrm{mg} / \mathrm{L}$. The total of BTEX in Lana River water samples are shown in Figure 8. Levels of BTEX in Lana River stations were from 0 to 15.0 $\mathrm{mg} / \mathrm{L}$. The average level in Lana River was 6.1
ug/L. It was the 1.5 time higher compared with the average level found in Tirana River. The polluted station was for LR7 station. Figure 9 shows the profile of BTEX in water samples of the Tirana River and Lana River, July 2016. Benzene was found more than other BTEX in both Tirana River and Lana River. The origin of BTEX in these ecosystems is mainly because of automobilist transport and oil pumps near the rivers. Discharges of the waste water in both rivers by many mechanical businesses could be other factor. Profile of BTEX in both rivers was: Benzene > Toluene $>$ Xylenes. 
$\mu g / l$

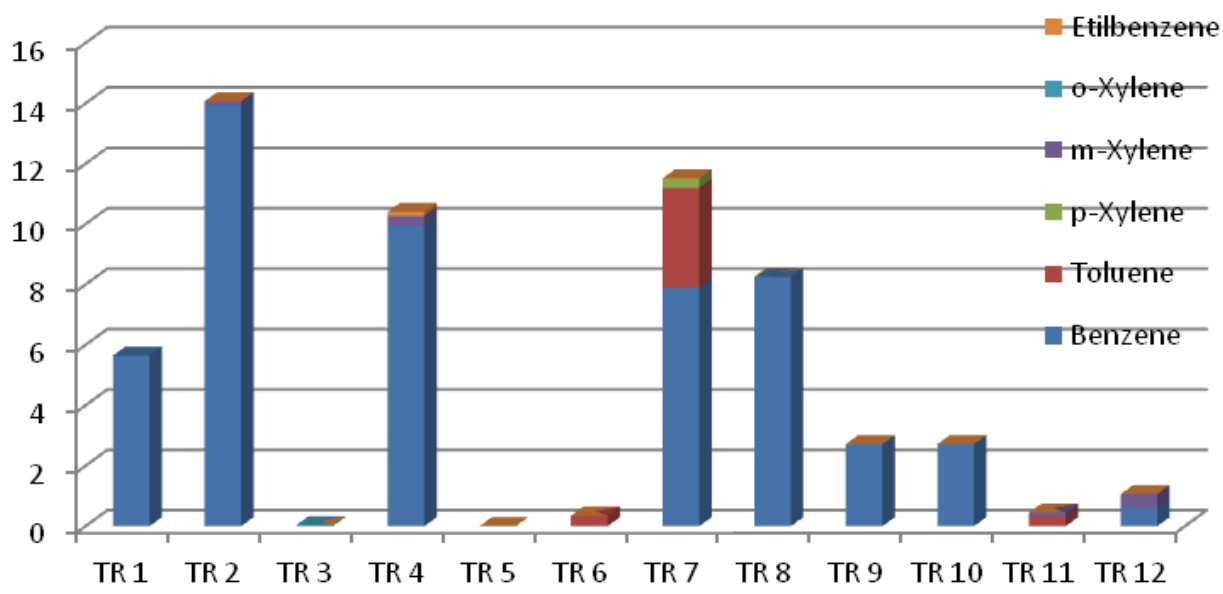

Figura 7. Total of BTEX in water samples of Tirana River, July 2016

Slika 7. Ukupna vrednost BTEX u uzorcima vode reke Tirana, juli 2016. $\mu g / l$

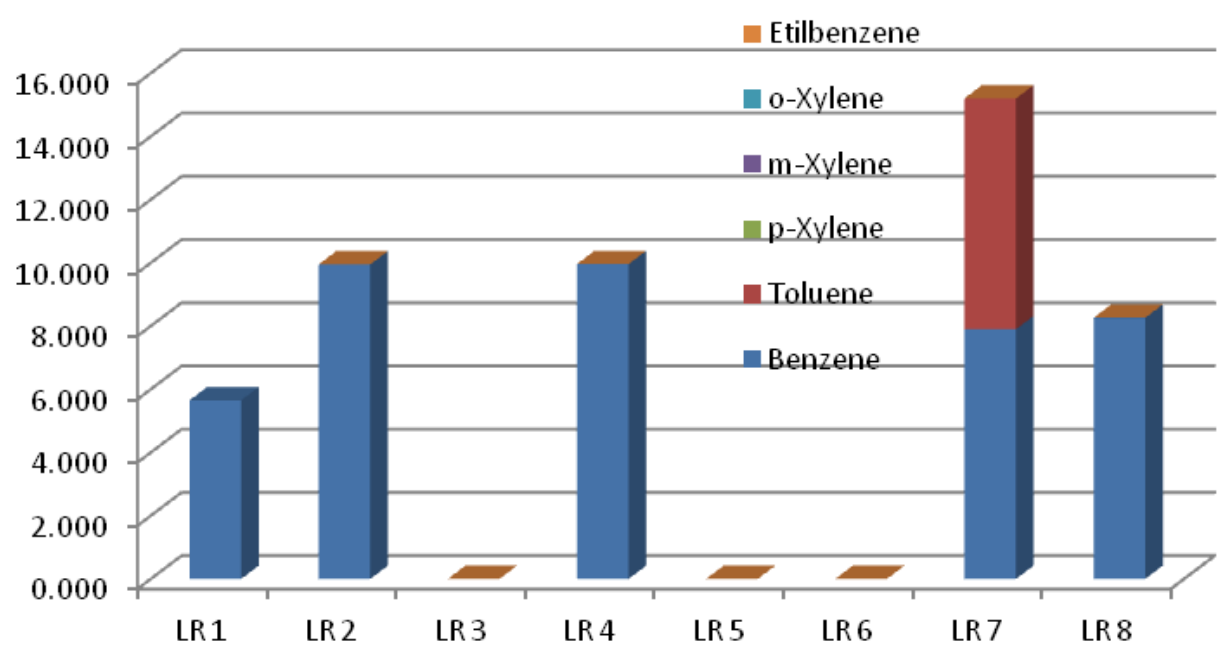

Figura 8. Total of BTEX in water samples of Lana River, July 2016

Slika 8. Ukupna vrednost BTEX u uzorcima vode reke Lana, juli 2016. $\mu g / l$

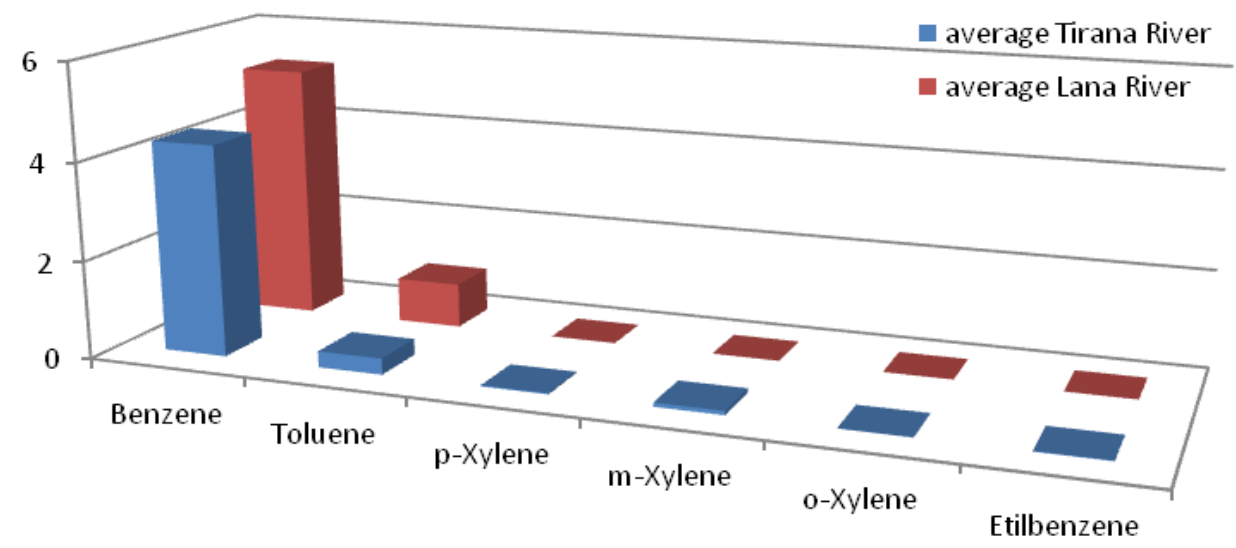

Figura 9. Profile of BTEX in water samples of Tirana and Lana River, July 2016.

Slika 9. Profil BTEX u uzorcima vode reka Tirana i Lana, juli 2016. 
Acenaphtalene, Fluorene, Phenanthrene, Antharcene, Pyrene, Benzo[a]Anthracene, Cryzene, Benzo[b]Fluoranthrene, Benzo[k]Fluoranthrene, Benzo[a]Pyrene, Dibenzo[a,h]Anthracene, Indeo $[1,2,3,-c d]$ Pyrene and Benzo[g,h,i]Perilene were $\mathrm{PAH}$ analyzed by using GC/FID technique. Total of PAHs in water samples of Tirana River was shown in Figure 10. Stations TR1, TR6, TR7, TR10 and TR11 were observed to have the maximum level with $1.4 \mathrm{mg} / \mathrm{L}$ while the minimum was for Station TR5 with $0.12 \mathrm{mg} / \mathrm{L}$. For all samples were observed presence of these pollutants almost in the same level except TR5 and TR9 stations. Total of PAHs in water samples of Lana River was shown in Figure 11. LR3 (9.4 mg/L), LR7 (10.6 $\mathrm{mg} / \mathrm{L})$ and LR8 $(3.0 \mathrm{mg} / \mathrm{L})$ were the most polluted

$\mu g / l$ stations with PAHs. In LR1 stations the PAHs weren't detected. Profile of PAHs in water samples of Tirana River and Lana River were shown in Figure 12. Profile of PAHs in Tirana River was different from profile of PAHs in Lana River. Profile of PAHs in water samples of Tirana River was: Benzo[a]anthracene > Cryzene > Anthracene. Profile of PAHs in Lana River was: Acenaphtalene $>$ Anthracene $>$ Fluorene $>$ Pyrene. Other PAHs for both rivers were not detected or were less than the limit of detection of GC/FID technique. Levels and profile of PAHs in Tirana and Lana rivers is associated with direct discharging of pumps oil near this area, car servicing, urban waters and automobile transport.

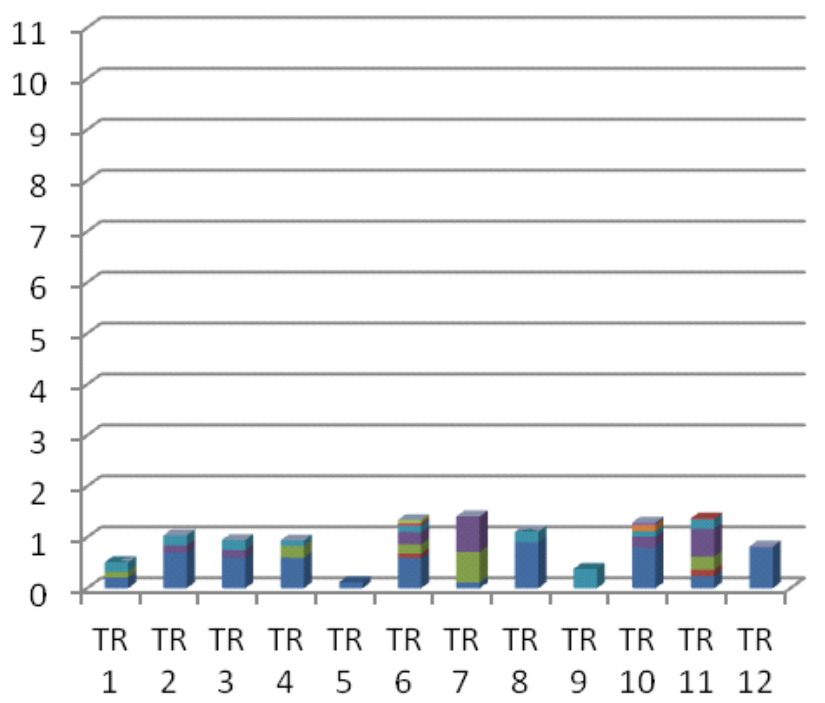

\author{
- Benzo [g,h,i] Perileni \\ - Indeo [1,2,3,-cd] pireni \\ - Dibenzo [a,h] antraceni \\ - Benzo [a] pireni \\ - Benzo [k] fluorantreni \\ Benzo [b] fluorantreni \\ - Krizeni \\ Benzo [a] antraceni \\ Pireni \\ - Antarceni \\ Fenantreni \\ - Fluoreni \\ - Acenaftaleni
}

Figura 10. Total of PAHs in water samples of Tirana River, July 2016. Slika 10. Ukupna vrednost PAHs u uzorcima vode reke Tirana, juli 2016. $\mu g / l$

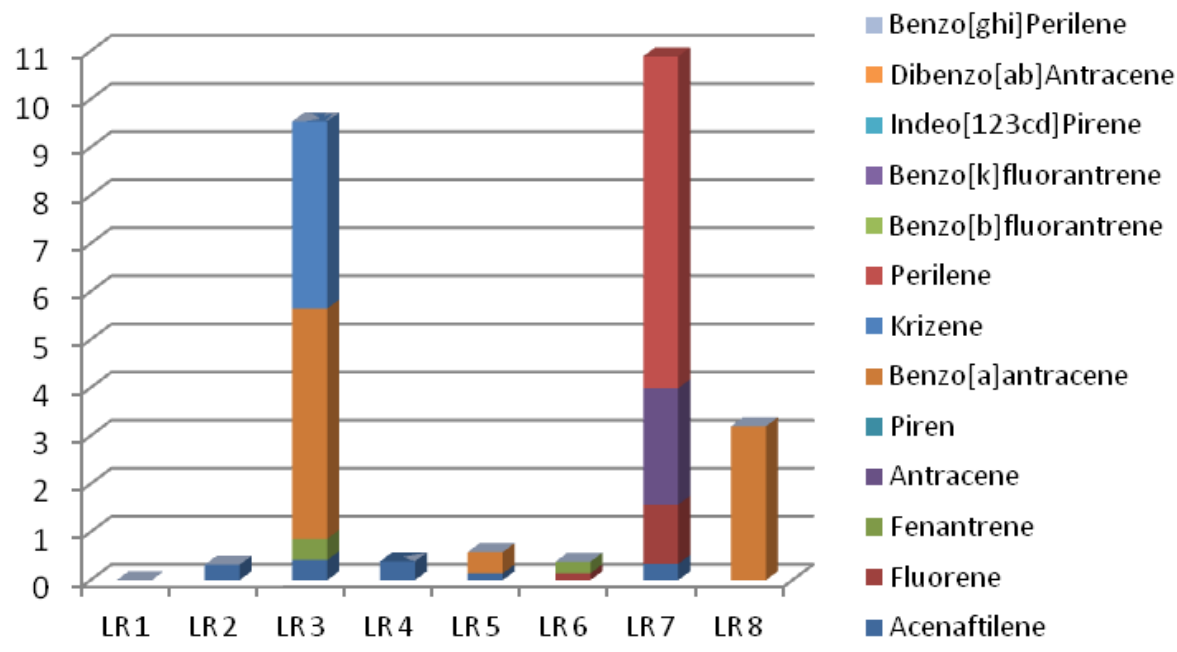

Figura 11. Total of PAHs in water samples of Lana River, July 2016.

Slika 11. Ukupna vrednost PAHs u uzorcima vode reke Lana, juli 2016. 


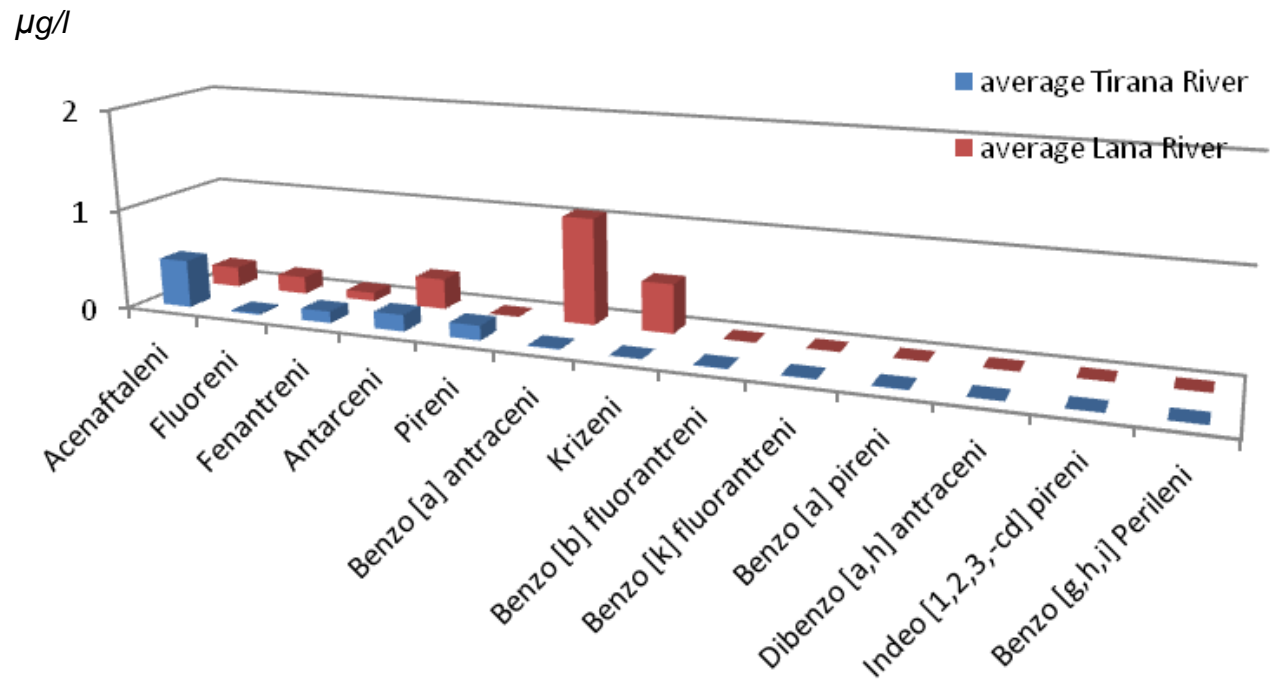

Figura 12. Profile of PAHs in water samples of Tirana River and Lana River, July 2016

Slika 12. Profil PAHs u uzorcima vode u rekama Tirana i Lana, jul 2016.

\section{CONCLUSIONS}

Analysis of organic pollutants in water samples and the Tirana River and Lana River was realized in July 2016. Chlorinated pesticides, their residues and PCB were studied using capillary GC/ECD. BTEX and PAH qualitative and quantitative analyze was conducted with capillary column with GC/FID technique. OCPs, PCBs and PAH were extracted using liquid-liquid extraction. Extraction and injection of BTEX were performed using Head Space mode.

The higher concentrations of organochlorine pesticides and PCBs were found for water samples of Tirana River because of their previous use, in the agricultural areas near the basin of this river. $\mathrm{HCH}$, Heptachlors and Aldrines were found more than other pesticides in Tirana River and Lana River. This fact is associated with previous uses of these compounds for agricultural purposes but also with the chemistry of each individual studied pollutant (mainly with the stability and solubility of pesticides and their residues in water samples). DDT was detected in few stations not only for its previous use but can be mostly because maybe of a point source of it near the river or river effluents. The higher concentrations were for volatile PCBs because of their atmospheric deposition in Albanian territory. Relatively high concentrations of BTEX and more volatile PAH compounds were detected in water samples of Lana River. Profile of BTEX in both rivers was: Benzene > Toluene > Xylenes. Profile of PAHs in Tirana River was different from profile of PAHs in Lana River. Profile of PAHs in water samples of Tirana River was: Benzo[a]anthracene > Cryzene > Anthracene.
Profile of PAHs in Lana River was: Acenaphtalene $>$ Anthracene $>$ Fluorene $>$ Pyrene. Other PAHs for both rivers were not detected or were less than the limit of detection of GC/FID technique. Levels and profile of PAHs in Tirana and Lana rivers is associated with direct discharging of pumps oil near this area, car servicing, urban waters and automobile transport.

\section{REFERENCES}

[1] A. Çullaj, A. Hasko, A. Miho, F. Schanz, H. Brandl, R. Bachofen (2005) Overview on Albanian natural waters and the human impact. Environment International 31(1):133-146.

[2] D. Erickson (2001) Introduction: PCB properties, uses, occurrence, and regulatory history. In: Robertson, Hansen L.W., Edison L.G., PCBs: Recent Advances in Environmental Toxicology and Health Effects. The University Press of Kentucky, Lexington, Kentucky, pp. 131-152.

[3] S. Safe (1994) Polychlorinated biphenyls (PCBs): environmental impact, biochemical and toxic responses, and implications for risk assessment. Criteria Revisit of Toxicology 24(2):87-149.

[4] International Agency for Research on Cancer (IARC). (1987) Benzene. Monographs on the evaluation of the carcinogenic risk of chemicals to humans, suppl. 7.Lyon: IARC.

[5] C. Hartmann, G. Quinn, W. Cairns, W. King (2004) The distribution and sources of polycyclic aromatic hydrocarbons in Narragansett Bay surface sediments. Marine Pollution Bulletin 48, 351-358.

[6] E. Gustafson, M. Dickhut (1997) Distribution of polycyclic aromatic hydrocarbons in southern Chesapeake Bay surface water: evaluation of three methods for determining freely dissolved water concentrations. Environment Toxicology Chemistry 16, 452-461. 
[7] USEPA 2009. Method EPA 524.3: Measurement of purgeable organic compounds in water by capillary column gas chromatography/mass spectrometry.

[8] J.C.F. Menendéz, L.F. Sánchez, J.E.S. Uría, E.F. Martínez, A. Sanz-Medel (2000) Static headspace, solid-phase microextraction and headspace solidphase microextraction for BTEX determination in aqueous samples by gas chromatography. Anal Chim Acta; p. 415:9-20.

[9] J.P. Villeneuve, F.P. Carvalho, M. Horvat, C. Cattini (2004) Worldwide intercomparison on the determination of chlorinated pesticides, PCBs and petroleum hydrocarbons in a mussel tissue homogenate, IAEA-142. Intern. J. Environ. Studies, $64 / 1$, pp. $437-452$
[10] G. Petrick, E. Schulz and J. Duinker (1988) Cleanup of environmental samles for analysis of Organochlorine compounds by gas chromatography with electron-capture detection. Journal of Chromatography, 435, 241-248.

[11] Ho-Sang Shin. 2012. Determination of MTBE, TBA and BTEX in Soil by Headspace Gas Chromatography-Mass Spectrometry. Bulletin of Korean Chemistry Society 33(5), 1693-1698.

[12] [A. Fernández, C. Alonso, J. González, M. Hernández (1998) Occurrence of organochlorine insecticides, PCBs and PCB congeners in waters and sediments of the Ebro River (Spain). Chemosphere 38, 33-43.

\section{IZVOD}

\section{ODREĐIVANJE NEKIH ORGANSKIH ZAGAĐIVAČA U VODAMA REKA GRADA TIRANA}

Ova rad prikazuje podatke o koncentraciji nekih organskih zagađivača u dve glavne reke u gradu Tirani: reke Lana, koja prolazi kroz grad, i reke Tirana, koja se nalazi na severoistoku grada. Izvršeno je uzorkovanje $i$ analiza na dvadeset tačaka na navedenim rekama. Uzorkovanje vode ostvareno je u julu 2016. Ove reke predstavljaju važne vodene površine grada Tirane $i$ šireg regiona u Albaniji. Na uzorcima iz reka su analizirani organohlorni pesticidi (organohlorirani pesticidi), njihovi produkti razgradnje, polihlorovani bisfenoli (PCBs), BTEX (benzen, toluen, etilbenzol i o-, m-, p-ksilen) i poliromantični ugljovodonici (PAH). Za određivanje organohloriranih pesticida (OCPs) i polihlorovanih bisfenola PCBs) iz uzoraka vode, korišćena je tečno-tečno (LLE) ekstrakcija i n-heksan kao ehstrahujući rastvarač. Nakon čišćenja i koncentracije, procedure za sve uzorke su bile da je izvršena analiza korišćenjem gasne hromatografije sa kapilarnom kolonom Rtx-5 (30m x $0.33 \mathrm{~mm} \times 0.25 \mu \mathrm{m})$ i korišćenjem elektronskog detektor (GC / ECD). Mikro ekstrakciona tehnika (HS-SPME) je korišćen da se prate BTEX u uzorcima vode. Za izolaciju $P A O$, korišćena je LLE ekstrakcija sa dihlorometanom kao ekstrakcijskim rastvaračem. Ekstrakti su koncentrovani, a zatim su injektirani u gasni hromatograf. Analiza BTEX i PAH u uzorcima vode izvedena je tehnikom gasnom hromatografijom uz korišćenje plameno jonizujućeg detektora (GC / FID). Injektovanje BTEX je izvedeno direktno koristeći Ofis-Space režima sa polidimetilsiloksan vlakna. VF-1ms capillare $(30 \mathrm{~m} \times 0.33 \mathrm{~mm} \times 0.25 \mathrm{um})$ su korišćene za odvajanje BTEX $i$ PAH jedinjenja.

Povećane koncentracije organohloriranih pesticida i PCBs pronađeni su u uzorcima vode iz reke Tirana zbog njihove upotrebe u poljoprivrednim područjima u blizini sliva ove reke. Povećanje koncentracije isparljive supstance PCBs je zbog njihovog prisustva $u$ atmosfiri na albanskoj teritoriji. Relativno visoke koncentracije BTEX $i$ više isparljivih PAH jedinjenja su detektovani $u$ uzorcima vode reke Lana. Prisustvo isparljivih organskih zagađivača može biti uglavnom zbog auto prevoza u blizini stanice, ispuštanje otpada iz nekih benzinskih pumpi ili neke mašinske industrije u vodotokove ovih reka.

Ključne reči: reka Tirana; reka Lana; OCP; PCB; BTEX; PAH; LLE; HS-SPME; GC/ECD; GC/FID

Naučni rad

Rad primljen: 12. 03. 2017.

Rad prihvaćen: 25. 04. 2017.

Rad je dostupan na sajtu: www.idk.org.rs/casopis

(c) 2017 Authors. Published by Inženjersko društvo za koroziju. This article is an open access article distributed under the terms and conditions of the Creative Commons Attribution 4.0 International license (https://creativecommons.org/licenses/by/4.0/) 